\title{
Fabrication of Pd-based metal-acid-alkali multifunctional catalysts for one-pot synthesis of MIBK
}

\author{
Rui Ma a,b, Yunpeng Li a,b, Guandong Wu ${ }^{a, b}$, Yufei He ${ }^{a, b, *}$, Junting Feng a,b, Yingying Zhao a,b,*, \\ Dianqing Li a,b \\ a State Key Laboratory of Chemical Engineering, Beijing University of Chemical Technology, Beijing 100029, China \\ b Beijing Engineering Center for Hierarchical Catalysts, Beijing University of Chemical Technology, Beijing 100029, China
}

\section{A R T I C L E I N F O}

\section{Article history:}

Received 26 February 2018

Accepted 24 April 2018

Published 5 August 2018

\section{Keywords:}

One-pot synthesis of methyl isobutyl ketone

Multifunctional catalyst

$\mathrm{Pd}$

$\mathrm{Mg}_{3} \mathrm{Al}$ mixed metal oxide

Synergy effect

Proximity

\begin{abstract}
A B S T R A C T
The one-pot synthesis of methyl isobutyl ketone (MIBK) from acetone using multifunctional catalysts is an important sustainable organic synthesis method with high atom and energy efficiency. Herein. we report a series of Pd supported on mixed metal oxide (MMO) catalysts with controllable acidic/basic/metallic sites on the surface. We study the relationship between the nature, synergy, and proximity of active sites and the catalytic performance of the multifunctional catalyst in the tandem reaction, in detail. In the existence of Lewis acid and base sites, the catalysts with medium-strength acidic/basic sites show preferred activity and/or MIBK selectivity. For multifunctional catalysts, the catalytic properties are more than just a collection of active sites, and the $\mathrm{Pd} / \mathrm{Mg}_{3} \mathrm{Al}-\mathrm{MMO}$ catalyst possessing $0.1 \% \mathrm{Pd}$ loading and $\sim 0.4$ acid/base molar ratio exhibits the optimal $42.1 \%$ acetone conversion and $37.2 \%$ MIBK yield, which is among the best reported so far for this tandem reaction under similar conditions. Moreover, the proximity test indicates that the intimate distance between acidic/basic/metallic sites can greatly shorten the diffusion time of the intermediate species from each active site, leading to an enhancement in the catalytic performance.
\end{abstract}

(C) 2018, Dalian Institute of Chemical Physics, Chinese Academy of Sciences. Published by Elsevier B.V. All rights reserved.

\section{Introduction}

Methyl isobutyl ketone (MIBK) is one of the most widely used aliphatic ketones, and is as an excellent solvent in the paint industry and an important reagent for dewaxing mineral oils [1-3]. Traditionally, MIBK is manufactured through a three-step process including the aldol condensation of acetone to diacetone alcohol (DAA), dehydration of DAA to mesityl oxide (MO), and hydrogenation of MO to MIBK. There are common problems in this three-step process, including the intermittent operation and multiple separation and purification of intermediate species. In addition, a homogeneous acid catalyst (sulfuric acid) and base catalyst (sodium carbonate) are widely used in the process, which causes severe environmental pollution and equipment corrosion [4,5]. Therefore, the conversion of acetone using a practical and efficient process will be highly beneficial. The one-pot synthesis strategy, allowing for different reactions to be carried out in a single vessel without complicated separation and purification between steps, is an alternative to stop-and-go syntheses and has economic and environmental benefits [6-8]. As for the one-pot synthesis of MIBK, the overall process is exothermic $(\Delta H=-117 \mathrm{~kJ} / \mathrm{mol})$, making

\footnotetext{
* Corresponding author. Fax: +86-10-64425385; E-mail: yfhe@mail.buct.edu.cn

\# Corresponding author. Fax: +86-10-64437866; E-mail: zhaoyy@mail.buct.edu.cn

This work was supported by the National Key Research and Development Program of China (2016YFB0301601), the National Natural Science Foundation (21706009) and the Fundamental Research Funds for the Central Universities (BUCTRC201725, JD1816).

DOI: 10.1016/S1872-2067(18)63092-X | http://www.sciencedirect.com/science/journal/18722067 | Chin. J. Catal., Vol. 39, No. 8, August 2018
} 
this cascade process a practicable reaction in thermodynamics $[9,10]$. However, the formation of DAA and MO is thermodynamically limited by unfavorable equilibria; therefore, it is vital to design a catalyst that can simultaneously drive these three steps. The development of heterogeneous multifunctional catalysts enables the one-pot tandem process to be carried out in an environmentally safe and efficient manner.

$\mathrm{Pd}$ and Pt, due to their excellent hydrogenation property, are commonly selected as the active metals in the one-pot synthesis of MIBK from acetone [11-15]. Therefore, studies of heterogeneous multifunctional catalysts for the tandem reaction mainly focus on designing and synthesizing suitable supports. For example, Lin et al. [16] reported a Na-modified MgO-supported Pd bifunctional catalyst that showed high acetone conversion due to the enhanced basic strength of the support. Wang et al. [17] deposited Pd nanoparticles on a chromium terephthalate MIL-101, and found that the high density and improved accessibility of acid sites $\left(\mathrm{Cr}^{3+}\right)$ led to high selectivity towards MIBK; however, this catalyst showed poor stability, with the activity decreasing by $40 \%$ after four usages. Furthermore, Robert's study indicated that strong acid sites could promote the dehydration of DAA to MO under mild reaction conditions [18]. In recent years, more and more new materials have been used in the one-pot synthesis of MIBK from acetone, and there is agreement in the literature that the combination of multiple active sites can shift the equilibrium of the condensation step in favor of MO by the simultaneous and irreversible hydrogenation to MIBK [19-21]. However, there have been few in-depth studies on the synergistic effect of these metallic/acidic/basic sites on multifunctional catalysts on the catalytic performance in this tandem reaction, let alone research on the effect of proximity of the multi-active sites.

Layered double hydroxides (LDHs) are a family of two-dimensional (2D) anionic clay materials with the general formula $\left[\mathrm{M}^{2+}{ }_{1-x} \mathrm{M}^{3+}{ }_{x}(\mathrm{OH})_{2}\right]^{x+}\left(\mathrm{A}^{n-}\right)_{x / n} \cdot m \mathrm{H}_{2} \mathrm{O}$, where $\mathrm{M}^{2+}$ and $\mathrm{M}^{3+}$ represent metallic cations and $\mathrm{A}^{n-}$ is a charge-balancing anion [22-24]. Based on the construction principle of LDHs, the metal cations within the brucite-like layers are uniformly distributed at the atomic level, and the ratio of $\mathrm{M}^{2+} / \mathrm{M}^{3+}$ can be tuned in a certain range [25]. In addition, LDHs possess abundant acidic and basic sites associated with the presence of $\mathrm{O}^{2-}-\mathrm{M}^{n+}$ acid-base pairs within the brucite-like layers [26]. Because of the uniform dispersion of $\mathrm{M}^{2+}$ and $\mathrm{M}^{3+}$ cations in the layers and the cation-tunability of LDH materials, the nature, strength and relative number of acidic/basic sites can be finely controlled. The memory effect is another important character of LDH materials; namely, LDHs can be converted to well-dispersed mixed metal oxides (MMO) by calcination at $450-600{ }^{\circ} \mathrm{C}$ and retain the nature of the brucite-like layers, such as highly dispersed metal cations and surface acidic/basic sites $[27,28]$. The large number of adjustable acidic/basic sites on MMOs makes it a class of excellent solid acid/base catalysts. Brucite-like hydrotalcite containing $\mathrm{Ni}^{2+}, \mathrm{Co}^{2+}$, or $\mathrm{Fe}^{2+}$ and $\mathrm{Pd} / \mathrm{MgAl}$-hydrotalcites have been reported as catalyst precursors or catalysts in the synthesis of MIBK, and the effect of either the acidity or alkalinity of hydrotalcites on catalytic performance have been intensively investigated [29-32]. However, there have been few in-depth studies on the synergistic effect of acidic/basic/metallic sites on catalytic performance in the tandem reaction, especially the effect of the number and proximity of acidic/basic/metallic sites.

In this paper, $\mathrm{Pd}$ supported on $\mathrm{MO}_{x}(\mathrm{M}=\mathrm{Ca}, \mathrm{Mg}, \mathrm{Al}, \mathrm{Ti})$ and active carbon were prepared for the one-pot synthesis of MIBK to study the effect of acidity and basicity over the bifunctional catalysts on the tandem reaction. A series of multifunctional catalysts with a combination of metallic/acidic/basic active sites were designed using LDH materials. By adjusting the metal ratio within the brucite-like layers of the LDH precursor, the relationship between the catalytic property and density of acidic/basic sites was revealed. We further studied the proximity of the three active sites on the catalytic performance by a physical mixing method, and a possible mechanism was proposed to demonstrate the synergistic effect of basic/acidic/metallic sites in the one-pot synthesis of MIBK from acetone. Moreover, the obtained $\mathrm{Pd} / \mathrm{Mg}_{3} \mathrm{Al}-\mathrm{MMO}$ multifunctional catalyst was optimized by using the deposition-precipitation method, followed by testing of the catalyst stability.

\section{Experimental}

\subsection{Materials}

Analytical-grade chemical reagents including $\mathrm{Mg}\left(\mathrm{NO}_{3}\right)_{2} \cdot 6 \mathrm{H}_{2} \mathrm{O}, \mathrm{Al}\left(\mathrm{NO}_{3}\right)_{3} \cdot 9 \mathrm{H}_{2} \mathrm{O}, \mathrm{TiO}_{2}, \mathrm{NaCl}, \mathrm{MgO}, \mathrm{TiCl}_{4}, \mathrm{MgO}$, $\mathrm{AlOOH}, \mathrm{Na}_{2} \mathrm{SO}_{3} \cdot 9 \mathrm{H}_{2} \mathrm{O}, \mathrm{PdCl}_{2}$, and urea were purchased from Sigma-Aldrich and used without further purification. The water used in all the experiments was deionized and had an electrical conductivity $<10^{-6} \mathrm{~S} / \mathrm{cm}$.

\subsection{Preparation of the support precursor}

The $\mathrm{Mg}_{x} \mathrm{Al}$-LDHs $(x=1,2,3,4,5)$ were prepared by a hydrothermal method. For example, to prepare $\mathrm{Mg}_{2} \mathrm{Al}-\mathrm{LDHs}, 7.52$ $\mathrm{g} \mathrm{Mg}\left(\mathrm{NO}_{3}\right)_{2} \cdot 6 \mathrm{H}_{2} \mathrm{O}, 5.48 \mathrm{~g} \mathrm{Al}\left(\mathrm{NO}_{3}\right)_{3} \cdot 9 \mathrm{H}_{2} \mathrm{O}$, and $6.19 \mathrm{~g}$ urea $(n$ (urea): $n\left(\mathrm{NO}^{3-}\right)=1: 1$ ) were dissolved in $70 \mathrm{~mL}$ of deionized water, then transferred into a $100 \mathrm{~mL}$ autoclave and aged at $150{ }^{\circ} \mathrm{C}$ for $6 \mathrm{~h}$. The resulting sediment was centrifuged and washed with deionized water several times until the $\mathrm{pH}$ reached 7. After drying at $70^{\circ} \mathrm{C}$ overnight, the $\mathrm{Mg}_{2} \mathrm{Al}-\mathrm{LDH}$ precursor was obtained. LDHs with other $\mathrm{Mg} / \mathrm{Al}$ ratios as well as Mg3 3 Ti-LDHs, MgAl 0.5 Ti0.5-LDHs, and Ca1.5Mg1.5Al-LDHs were prepared via the same method.

The Ca3Ti-LDH precursor was prepared by a deposition-precipitation method. A $\mathrm{NaOH}(1.0 \mathrm{~mol} / \mathrm{L})$ and $\mathrm{Ca}(\mathrm{OH})_{2}$ mixed solution was added to $\mathrm{TiCl}_{4}$ (dissolved in diluted $\mathrm{HCl}$ with the volume proportion of $1: 1$ ) at constant $\mathrm{pH}=12$. The final product was filtered, washed thoroughly with deionized water, and dried overnight at $70^{\circ} \mathrm{C}$.

\subsection{Preparation of supported Pd catalysts}

Pd was deposited on various supports $\left(\mathrm{MgO}, \mathrm{Al}_{2} \mathrm{O}_{3}, \mathrm{TiO}_{2}, \mathrm{C}\right.$, MgxAl-LDHs, $\quad \mathrm{Mg}_{3} \mathrm{Ti}$-LDHs, Ca3Ti-LDHs, MgAlo.5Ti0.5-LDHs, 
Ca1.5 $\mathrm{Mg}_{1.5} \mathrm{Al}$-LDHs) using an impregnation method. Typically, $3.0 \mathrm{~g}$ support was suspended in $25 \mathrm{~mL}$ of $\mathrm{Na}_{2} \mathrm{PdCl}_{4}$ aqueous solution with $0.1 \%$ nominal Pd loading, then stirred vigorously at $80^{\circ} \mathrm{C}$ until the water was removed by evaporation. Subsequently, the powder was dried at $80^{\circ} \mathrm{C}$ for $5 \mathrm{~h}$, followed by calcination at $450{ }^{\circ} \mathrm{C}$ in air for $2 \mathrm{~h}$, and reduction in $10 \% \mathrm{H}_{2} / \mathrm{Ar}$ at $450{ }^{\circ} \mathrm{C}$ for $5 \mathrm{~h}$. Pd/CaO was prepared by depositing $\mathrm{Pd}$ on $\mathrm{Ca}(\mathrm{OH})_{2}$, calcining at $700{ }^{\circ} \mathrm{C}$, and then reducing at $450{ }^{\circ} \mathrm{C}$ for $5 \mathrm{~h}$ in a $10 \% \mathrm{H}_{2} / \mathrm{Ar}$ stream. The corresponding catalysts were denoted $\mathrm{Pd} / \mathrm{MgO}, \mathrm{Pd} / \mathrm{Al}_{2} \mathrm{O}_{3}, \mathrm{Pd} / \mathrm{TiO}_{2}, \mathrm{Pd} / \mathrm{C}, \mathrm{Pd} / \mathrm{Mg}_{\mathrm{x}} \mathrm{Al}-\mathrm{MMO}$, $\mathrm{Pd} / \mathrm{Mg}_{3} \mathrm{Ti}-\mathrm{MMO}, \mathrm{Pd} / \mathrm{Ca}_{3} \mathrm{Ti}-\mathrm{MMO}, \mathrm{Pd} / \mathrm{MgAl}_{0.5} \mathrm{Ti}_{0.5}-\mathrm{MMO}$, and $\mathrm{Pd} / \mathrm{Ca}_{1.5} \mathrm{Mg}_{1.5} \mathrm{Al}-\mathrm{MMO}$. A Pd/Mg $\mathrm{Al}$-MMO catalyst with $0.1 \% \mathrm{Pd}$ loading was also synthesized by a deposition-precipitation method (DP). First, $3.0 \mathrm{~g}$ of $\mathrm{Mg}_{3} \mathrm{Al}-\mathrm{MMO}$ powder was mixed with $10 \mathrm{~mL}$ of deionized water, and then a designated amount of $\mathrm{NaOH}$ solution was added to the mixture to obtain a fixed $\mathrm{pH}$ of 12 . Subsequently, a $\mathrm{Na}_{2} \mathrm{PdCl}_{4}$ aqueous solution $(3.0 \mathrm{~mL}, 10.0$ $\mathrm{mmol} / \mathrm{L}$ ) was added dropwise, and the suspension was stirred for $5 \mathrm{~h}$ at room temperature, followed by a centrifugation process, drying at $80^{\circ} \mathrm{C}$ overnight, calcination at $450{ }^{\circ} \mathrm{C}$ in air for 2 $\mathrm{h}$, and reduction in $10 \% \mathrm{H}_{2} / \mathrm{Ar}$ stream for $5 \mathrm{~h}$. The obtained catalyst was denoted $\mathrm{Pd} / \mathrm{Mg}_{3} \mathrm{Al}-\mathrm{MMO} \mathrm{DP}_{\mathrm{DP}}$.

\subsection{Characterization}

The specific surface area of the samples was calculated according to the Brunauer-Emmett-Teller (BET) method using a Quantachrome Autosorb-1 system. X-ray diffraction (XRD) measurements were carried out on a Rigaku UItima III X-ray powder diffractometer ( $\mathrm{Cu} K_{\alpha}$ radiation) at a scanning rate of $10^{\circ} / \mathrm{min}$. Chemical analysis was performed using inductively coupled plasma emission spectroscopy (ICP-AES, Shimadzu ICPS-75000). The morphology and particle size of the Pd particles were observed by a JEOL-2100F HRTEM.

$\mathrm{CO}_{2}$ and $\mathrm{NH}_{3}$ temperature-programmed desorption (TPD) of the samples was conducted on a Micrometric ChemiSorb 2750 chemisorption instrument with a thermal conductivity detector (TCD). About $0.10 \mathrm{~g}$ of a sample was loaded in a quartz reactor. Before $\mathrm{CO}_{2}$-TPD and $\mathrm{NH}_{3}$-TPD, the samples were kept in a stream of $\mathrm{CO}_{2} / \mathrm{NH}_{3}$ until the adsorption was saturated, followed by treatment with $\mathrm{He}$ for $30 \mathrm{~min} . \mathrm{CO}_{2} / \mathrm{NH}_{3}$-TPD signals were recorded from 50 to $500{ }^{\circ} \mathrm{C}$ with a He flow rate of 40 $\mathrm{mL} / \mathrm{min}$ and a temperature ramp of $10^{\circ} \mathrm{C} / \mathrm{min}$.

In situ diffuse reflectance Fourier transform infrared (FT-IR) spectroscopy of $\mathrm{CO}_{2}$ was carried out via a Bruker Tensor 27 instrument. The catalyst was pretreated under $\mathrm{N}_{2}$ flow at $100{ }^{\circ} \mathrm{C}$ for $1 \mathrm{~h}$, followed by a background recording at a resolution of $4 \mathrm{~cm}^{-1}$. The catalyst was then exposed to $\mathrm{CO}_{2}$ flow for another $1 \mathrm{~h}$. Sample scanning of chemisorption on the catalysts was conducted under $10^{-4}$ mbar at room temperature.

Py-IR spectra were detected on a Thermo Nicolet FT-IR spectrometer. The solid sample was pretreated under $\mathrm{H}_{2}$ at 450 ${ }^{\circ} \mathrm{C}$ for $1 \mathrm{~h}$. The solid sample (30 mg) was then pressed into a self-supporting wafer and treated under $\mathrm{N}_{2}$ at $200{ }^{\circ} \mathrm{C}$ for $1 \mathrm{~h}$. The background spectrum was recorded after cooling to room temperature. Pyridine was introduced into the sample for 60 min. Finally, the spectrum was recorded with a $4 \mathrm{~cm}^{-1}$ resolu- tion in the range of $1675-1400 \mathrm{~cm}^{-1}$.

\subsection{Reaction system and procedure}

The general process of the one-pot synthesis of MIBK in liquid catalyzed by the solid catalysts is as follows. The test was performed in a $25 \mathrm{~mL}$ stainless steel autoclave provided with a pressure gauge and a magnetic stirrer. Typically, the autoclave was charged with $0.35 \mathrm{~g}$ of catalyst and $10 \mathrm{~mL}$ of acetone. Before the reaction, the autoclave was purged three times with $\mathrm{H}_{2}$, followed by pressurizing with $\mathrm{H}_{2}$ to $1.8 \mathrm{MPa}$. Then, the autoclave was heated to $120{ }^{\circ} \mathrm{C}$ with a speed of $220 \mathrm{r} / \mathrm{min}$. When the temperature rose to $120^{\circ} \mathrm{C}$, the $\mathrm{H}_{2}$ pressure increased to 2.8 $\mathrm{MPa}$, and the experiment was carried out for $5 \mathrm{~h}$. In summary, the reactions were all carried out in a $25 \mathrm{~mL}$ autoclave with $10 \mathrm{~mL}$ of acetone and $0.35 \mathrm{~g}$ of catalyst, and were kept at $120^{\circ} \mathrm{C}$ for $5 \mathrm{~h}$ under $2.8 \mathrm{MPa} \mathrm{H}_{2}$ atmosphere. After the reaction, the autoclave was cooled using an ice bath, and the reaction mixture was separated from the catalyst by filtering. Analysis of the liquid product was performed in a GC-FID (Agilent 7890B) with a capillary column (DB-WAX), using $n$-propanol as the internal standard. The carbon balance determined from the liquid products was $(100 \pm 2) \%$. The conversion of acetone, selectivity of each product, and yield of MIBK are defined as follows:

Acetone coversion $=(1-\mathrm{mol}$ of acetone in the product $/ \mathrm{mol}$ of acetone in the end) $\times 100 \%$

Selectivity of products $=(\mathrm{mol}$ of acetone converted to the product $/ \mathrm{mol}$ of acetone reacted) $\times 100 \%$

MIBK yield $=$ acetone conversion $\times$ selectivity of MIBK.

\section{Results and discussion}

\subsection{Synthesis of MIBK from acetone over bifunctional catalysts}

The one-pot synthesis of MIBK from acetone is a green and economic process, including the condensation of acetone, dehydration of diacetone alcohol, and selective hydrogenation of the $\mathrm{C}=\mathrm{C}$ bond. To determine the role of acidic and basic sites in the tandem reaction, supported Pd bifunctional catalysts were synthesized and then used in this process. As shown in Table 1, $\mathrm{Pd}$ loaded on both acidic supports $\left(\mathrm{Al}_{2} \mathrm{O}_{3}\right.$ and $\left.\mathrm{TiO}_{2}\right)$ and basic supports ( $\mathrm{MgO}$ and $\mathrm{CaO}$ ) can convert acetone to produce MIBK. However, Pd supported on active carbon, which is a common neutral carrier, is inactive. Moreover, about 30\% acetone conversion was achieved by the $\mathrm{Pd} /$ base bifunctional catalyst, which is almost 2-3 times that of the Pd/acid catalyst, indicating that the basic sites on the catalyst favor the condensation step. IR and TPD were also used to characterize the type and strength of the acidity and basicity on these catalysts, and the results are shown in Fig. S1. For Pd/base catalysts, the adsorption of bridged carbonates in the $\mathrm{CO}_{2}$-IR spectrum indicates that only the L-basic sites were present on $\mathrm{Pd} / \mathrm{CaO}$ and $\mathrm{Pd} / \mathrm{MgO}$, and the basic strength of the $\mathrm{Pd} / \mathrm{CaO}$ catalyst was stronger than that of $\mathrm{Pd} / \mathrm{MgO}[33,34]$. As for the Pd/acid catalyst, only L-acid sites existed on $\mathrm{Pd} / \mathrm{Al}_{2} \mathrm{O}_{3}$ and $\mathrm{Pd} / \mathrm{TiO}_{2}$, and the order of acid strength was $\mathrm{Pd} / \mathrm{TiO}_{2}>\mathrm{Pd} / \mathrm{Al}_{2} \mathrm{O}_{3}$ [35]. Although 
Table 1

Catalytic properties of supported Pd bifunctional catalysts.

\begin{tabular}{|c|c|c|c|c|c|c|c|c|}
\hline \multirow{2}{*}{ Sample } & \multirow{2}{*}{$\begin{array}{l}\text { Pd loading } \\
\text { (\%) }\end{array}$} & \multirow{2}{*}{$\begin{array}{l}\text { Particle size } \\
\text { (nm) }\end{array}$} & \multirow{2}{*}{$\begin{array}{c}\text { Acetone conversion } \\
(\%)\end{array}$} & \multicolumn{4}{|c|}{ Selectivity (\%) } & \multirow{2}{*}{$\begin{array}{c}\text { Yield of MIBK } \\
(\%)\end{array}$} \\
\hline & & & & DAA & MO & MIBK & Others* & \\
\hline $\mathrm{Pd} / \mathrm{Al}_{2} \mathrm{O}_{3}$ & 0.11 & 4.1 & 11.2 & 3.4 & 0.5 & 92.3 & 3.8 & 10.3 \\
\hline $\mathrm{Pd} / \mathrm{TiO}_{2}$ & 0.10 & 4.2 & 17.5 & 1.0 & 34.9 & 62.1 & 2.0 & 10.9 \\
\hline Pd/MgO & 0.09 & 4.2 & 30.7 & 1.0 & 1.7 & 90.0 & 7.4 & 27.6 \\
\hline $\mathrm{Pd} / \mathrm{CaO}$ & 0.10 & 4.5 & 33.1 & 18.8 & 1.3 & 72.0 & 7.9 & 23.9 \\
\hline $\mathrm{Pd} / \mathrm{C}$ & 0.11 & 3.9 & 0.0 & 0.0 & 0.0 & 0.0 & 0.0 & 0.0 \\
\hline
\end{tabular}

* Byproducts including propene, propane, isopropanol and some higher acetone condensation products.

the stronger basicity results in a higher acetone conversion, the $\mathrm{Pd} / \mathrm{CaO}$ catalyst showed poor selectivity to MIBK compared to that of $\mathrm{Pd} / \mathrm{MgO}$, suggesting that stronger basic sites are not good for the dehydration of DAA to produce MO. In this tandem reaction, the total selectivity to MIBK + MO indicates that dehydration of the intermediate DAA occurred. In the case of the $\mathrm{Pd} /$ acid bifunctional catalyst, the selectivity to MIBK + MO of the $\mathrm{Pd} / \mathrm{Al}_{2} \mathrm{O}_{3}$ and $\mathrm{Pd} / \mathrm{TiO}_{2}$ catalysts was higher than that for the $\mathrm{Pd} /$ base bifunctional catalyst, which suggests that acidic sites are favorable for the dehydration of DAA.

From the evaluation of the bifunctional catalyst, it was found that basic sites favored the condensation of acetone and different basic strengths showed distinct dehydration abilities. Meanwhile, although the Pd/acid catalyst showed limited acetone conversion, acid sites can effectively inhibit the occurrence of side reactions. In addition, there is a significant difference in the interaction between different strengths of acid sites and Pd particles, affecting the ability of MO hydrogenation to produce MIBK. The results of the catalytic performance of $\mathrm{Pd} /$ acid or $\mathrm{Pd} /$ base bifunctional catalysts indicate that various active sites play different roles in the specific stages of the tandem reaction, and therefore, it will certainly be of interest to design multifunctional catalysts containing acidic/basic/metallic active sites and investigate the relationship between active sites and catalytic performance.

\subsection{Catalytic properties of Pd/MMO multifunctional catalysts}

Multi-site catalysts containing acidic, basic and metallic sites were prepared by the introduction of Pd on LDH materials that possess consecutive acid and basic sites, followed by the calcination and reduction process. The obtained Pd/MMO catalysts were then used in the tandem reaction, and the results are listed in Table 2. It was found that the catalytic properties of the multifunctional catalysts were more than just a collection of active sites, and both positive and negative synergistic effects were involved. In detail, Pd/Mg3Ti-MMO, Pd/CaзTi-MMO, and
$\mathrm{Pd} / \mathrm{Ca}_{1.5} \mathrm{Mg}_{1.5} \mathrm{Al}-\mathrm{MMO}$ containing different strengths of acidic and basic sites showed reduced acetone conversion $(<13 \%)$ and poorer selectivity to MIBK $(<76 \%)$ compared with the corresponding bifunctional catalysts. However, the $\mathrm{Pd} / \mathrm{Mg}_{3} \mathrm{Al}-\mathrm{MMO}$ catalyst exhibited enhanced acetone conversion (38\%) and MIBK yield (31.6\%) due to a positive synergistic effect. Moreover, the yield of MIBK was significantly reduced when Ti was introduced into $\mathrm{Mg}_{3} \mathrm{Al}-\mathrm{MMO}$ (control of acidic sites on MMO), indicating that the tandem reaction process is sensitive to the strength and density of acidic and basic sites on the multifunctional catalysts; even a slight change in the properties of the acidic/basic sites can obviously affect the specific processes in this tandem reaction. Thus, it is indispensable to design a series of acid-base supports with a continuously adjustable density of acidic/basic sites to study the synergistic effect between the acidic sites and basic sites in detail.

\subsection{Role of the synergistic effect of acidic/basic sites}

Due to the properties of the LDHs, it is feasible to fine-tune the acidic/basic sites by regulating the composition of the lamellar metals. A series of Pd/MgxAl-MMO multifunctional catalysts with $\mathrm{Mg} / \mathrm{Al}$ atomic ratios from 1:1 to 5:1 were prepared by the LDH precursor method for the investigation of the relative amounts and synergistic effect of acidic/basic sites on catalytic performance in the one-pot synthesis of MIBK from acetone. XRD analysis was used to investigate the structure of the $\mathrm{Pd} / \mathrm{Mg}_{x} \mathrm{Al}-\mathrm{MMO}$ catalysts with different $\mathrm{Mg} / \mathrm{Al}$ molar ratios. As shown in Fig. 1(a), it is noteworthy that no $\mathrm{Al}_{2} \mathrm{O}_{3}$ characteristic peaks were observed, indicating that alumina was present in an amorphous form [36]. The diffraction peaks of $\mathrm{MgO}$ (PDF\#45-1946) were detected in all five catalysts, and with increasing $\mathrm{Mg}$ content, the intensity of the characteristic diffraction peak increased gradually. No Pd characteristic diffraction peaks were detected, possibly because of the relatively low Pd loading. The dispersion of the supported palladium on five multifunctional catalysts (Pd/Mg $\mathrm{Al}-\mathrm{MMO}(x=1,2,3,4,5))$ was

Table 2

Catalytic properties of some Pd-based mixed metal oxides.

\begin{tabular}{|c|c|c|c|c|c|c|c|c|}
\hline \multirow{2}{*}{ Sample } & \multirow{2}{*}{$\begin{array}{c}\text { Pd loading } \\
(\%)\end{array}$} & \multirow{2}{*}{$\begin{array}{c}\text { Acetone conversion } \\
(\%)\end{array}$} & \multirow{2}{*}{$\begin{array}{c}\text { Yield of MIBK } \\
(\%)\end{array}$} & \multicolumn{5}{|c|}{ Selectivity (\%) } \\
\hline & & & & DAA & MO & MIBK & IPA & Others \\
\hline $\mathrm{Pd} / \mathrm{Mg}_{3} \mathrm{Al}-\mathrm{MMO}$ & 0.12 & 38.2 & 31.6 & 3.0 & 7.4 & 82.8 & 1.5 & 5.3 \\
\hline $\mathrm{Pd} / \mathrm{Mg}_{3} \mathrm{Ti}-\mathrm{MMO}$ & 0.10 & 12.9 & 7.0 & 2.7 & 0.2 & 54.5 & 41.9 & 0.7 \\
\hline $\mathrm{Pd} / \mathrm{Ca}_{3} \mathrm{Ti}-\mathrm{MMO}$ & 0.11 & 6.2 & 4.7 & 6.4 & 0.9 & 76.2 & 13.2 & 3.4 \\
\hline $\mathrm{Pd} / \mathrm{Ca}_{1.5} \mathrm{Mg}_{1.5} \mathrm{Al}-\mathrm{MMO}$ & 0.11 & 9.0 & 4.5 & 0.2 & 0.0 & 50.1 & 48.6 & 1.1 \\
\hline $\mathrm{Pd} / \mathrm{Mg}_{3} \mathrm{Al}_{0.5} \mathrm{Ti}_{0.5}-\mathrm{MMO}$ & 0.09 & 21.6 & 20.1 & 1.9 & 0.1 & 93.0 & 2.7 & 2.2 \\
\hline
\end{tabular}

* Byproducts including propene, propane, isopropanol and some higher acetone condensation products. 

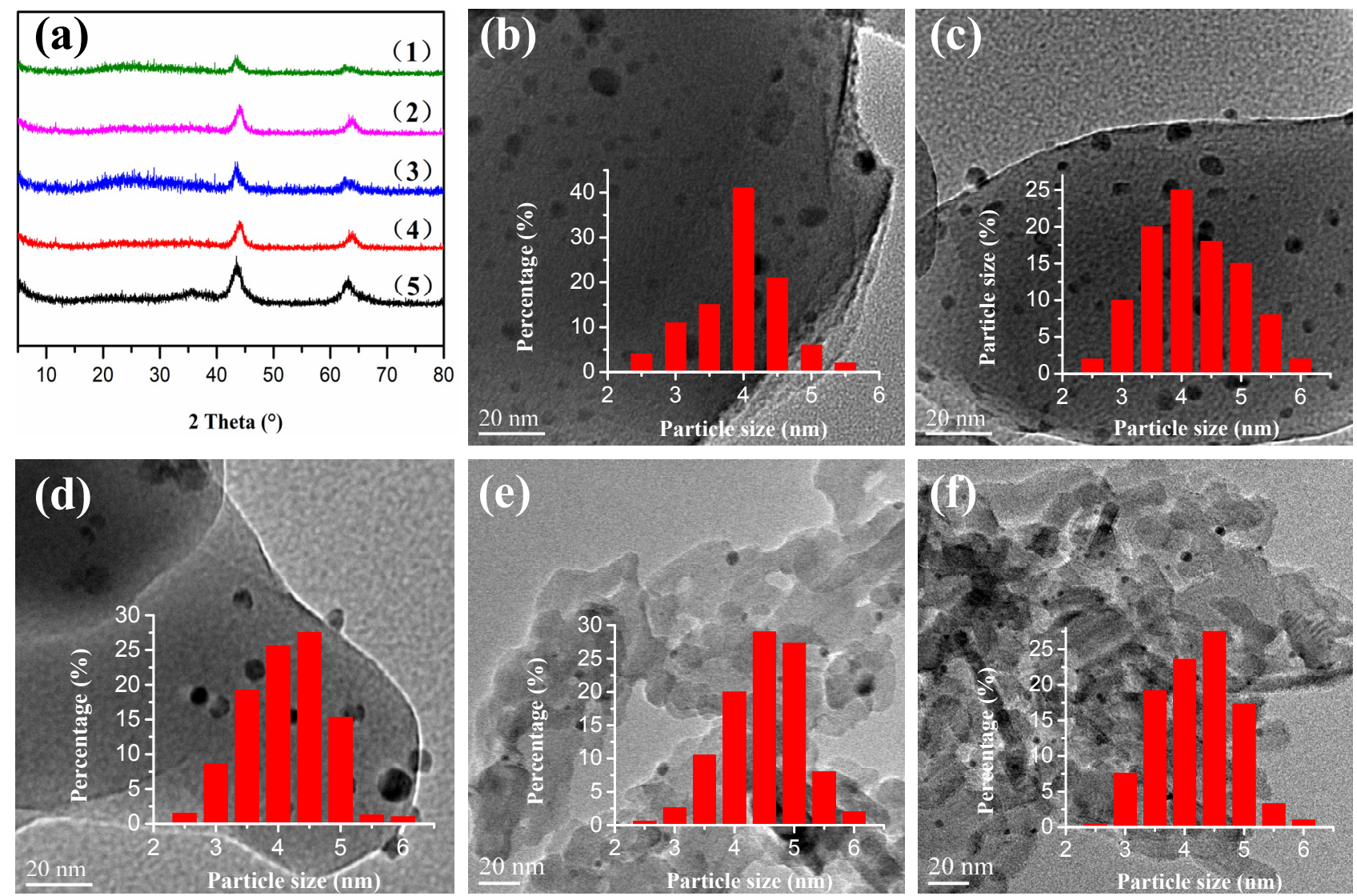

Fig. 1. (a) XRD patterns of Pd/Mg $1 \mathrm{Al}-\mathrm{MMO}$ (1), Pd/Mg $2 \mathrm{Al}-\mathrm{MMO}$ (2), Pd/Mg $\mathrm{Ml}_{3} \mathrm{MMO}$ (3), $\mathrm{Pd} / \mathrm{Mg}_{4} \mathrm{Al}-\mathrm{MMO}$ (4), and Pd/Mg $5 \mathrm{Al}-\mathrm{MMO}$ catalysts (5), and

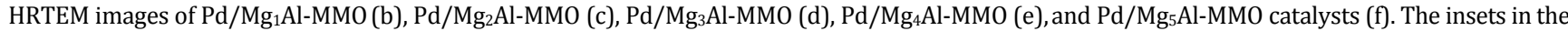
corresponding HRTEM images show the particle size frequency distribution histograms.

investigated using HRTEM. As shown in Fig. 1(b)-(f), these catalysts had a uniform size distribution between 2-6 $\mathrm{nm}$ without obvious aggregation. The mean diameters of the $\mathrm{Pd} / \mathrm{Mg}_{x} \mathrm{Al}-\mathrm{MMO}(x=1,2,3,4,5)$ samples were 4.3, 4.4, 4.6, 4.5, and $4.3 \mathrm{~nm}$. In addition, the $\mathrm{Pd}, \mathrm{Mg}$, and $\mathrm{Al}$ content of the five catalysts were determined. As listed in Table $3, \mathrm{Mg} / \mathrm{Al}$ atomic mole ratios and $\mathrm{Pd}$ loading in the obtained catalysts roughly correspond to the feed ratio. Combined with the specific surface area results, it can be concluded that the different ratios of $\mathrm{Mg} / \mathrm{Al}$ upon the $\mathrm{Mg}_{x} \mathrm{Al}-\mathrm{MMO}$ supports had little influence on the dispersion of the active metal.

Due to the importance of the acidic and basic sites in the tandem reaction, in situ IR of pyridine and $\mathrm{CO}_{2}$ was used to identify the types of acidic/basic sites over $\mathrm{Pd} / \mathrm{Mg}_{x} \mathrm{Al}-\mathrm{MMO}$ catalysts. The FT-IR spectra of pyridine adsorption onto the samples are shown in Fig. 2(a), and it was observed that all catalysts exhibited bands at $1450 \mathrm{~cm}^{-1}$, assigned to pyridine bound to Lewis acid sites [37,38]. No band around $1540 \mathrm{~cm}^{-1}$ was observed, indicating the absence of Brönsted acid sites [39]. The basicity of catalysts was determined by $\mathrm{IR}$ of $\mathrm{CO}_{2}$ adsorption. Fig. 2(b) shows that the peaks of $\mathrm{CO}_{2}$ adsorption on all catalysts' basic sites were the same, indicating the same type of surface basic sites [40]. The bridged carbonates (1690 and $1260 \mathrm{~cm}^{-1}$ ) were formed on the $\mathrm{Mg}^{2+}$ and $\mathrm{Mg}^{2+-} \mathrm{O}^{2-}$ pairs $[41,42]$. The above results show that the modulation of $\mathrm{Mg} / \mathrm{Al}$ ratio has no effect on the acid/base type.

To further quantitate the number of acidic/basic sites on $\mathrm{Pd} / \mathrm{Mg}_{\mathrm{x}} \mathrm{Al}-\mathrm{MMO}$ catalysts, $\mathrm{CO}_{2}$ and $\mathrm{NH}_{3}$-TPD analyses were

Table 3

Physicochemical properties of the series catalysts.

\begin{tabular}{|c|c|c|c|c|c|}
\hline Sample & $\begin{array}{c}\text { Surface area a } \\
\left(\mathrm{m}^{2} / \mathrm{g}\right)\end{array}$ & $\mathrm{Mg} / \mathrm{Al}$ ratio ${ }^{\mathrm{b}}$ & $\begin{array}{c}\text { Pd loading b } \\
(\%)\end{array}$ & $\begin{array}{c}\text { Acidic sites }{ }^{\mathrm{c}} \\
\left(\mu \mathrm{mol} \text { of } \mathrm{NH}_{3} / \mathrm{g} \text { of catalyst }\right)\end{array}$ & $\begin{array}{c}\text { Basic sites }^{\mathrm{d}} \\
\left(\mu \mathrm{mol} \text { of } \mathrm{CO}_{2} / \mathrm{g} \text { of catalyst }\right)\end{array}$ \\
\hline $\mathrm{Pd} / \mathrm{Mg}_{1} \mathrm{Al}-\mathrm{MMO}$ & 30 & 0.9 & 0.11 & 115 & 102 \\
\hline $\mathrm{Pd} / \mathrm{Mg}_{2} \mathrm{Al}-\mathrm{MMO}$ & 29 & 1.8 & 0.12 & 95 & 120 \\
\hline $\mathrm{Pd} / \mathrm{Mg}_{3} \mathrm{Al}-\mathrm{MMO}$ & 26 & 2.6 & 0.10 & 72 & 175 \\
\hline $\mathrm{Pd} / \mathrm{Mg}_{4} \mathrm{Al}-\mathrm{MMO}$ & 28 & 3.3 & 0.12 & 50 & 203 \\
\hline $\mathrm{Pd} / \mathrm{Mg}_{5} \mathrm{Al}-\mathrm{MMO}$ & 28 & 4.4 & 0.12 & 23 & 228 \\
\hline
\end{tabular}

a Determined by BET analysis.

b Determined by ICP-AES analysis.

c,d Calibrated using $1 \mu \mathrm{L}$ of $\mathrm{NH}_{3}$ and $\mathrm{CO}_{2}$ as standards. 

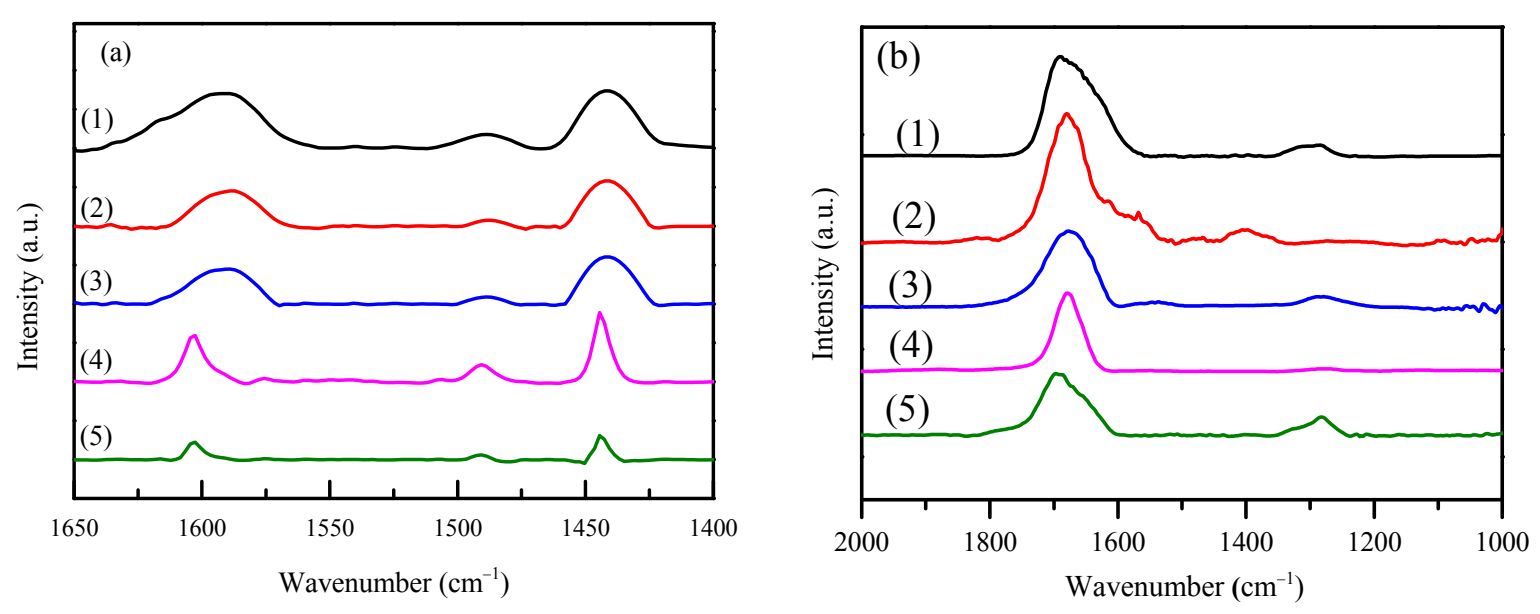

Fig. 2. Py-IR (a) and $\mathrm{CO}_{2}-\mathrm{IR}(\mathrm{b})$ spectra of Pd/Mg $1 \mathrm{Al}-\mathrm{MMO}$ (1), Pd/Mg $\mathrm{Al}-\mathrm{MMO}$ (2), $\mathrm{Pd} / \mathrm{Mg}_{3} \mathrm{Al}-\mathrm{MMO}$ (3), Pd/Mg $\mathrm{MAl}_{4} \mathrm{MMO}$ (4), and Pd/Mg $\mathrm{Ml}-\mathrm{MMO}$ (5) multifunctional catalysts.

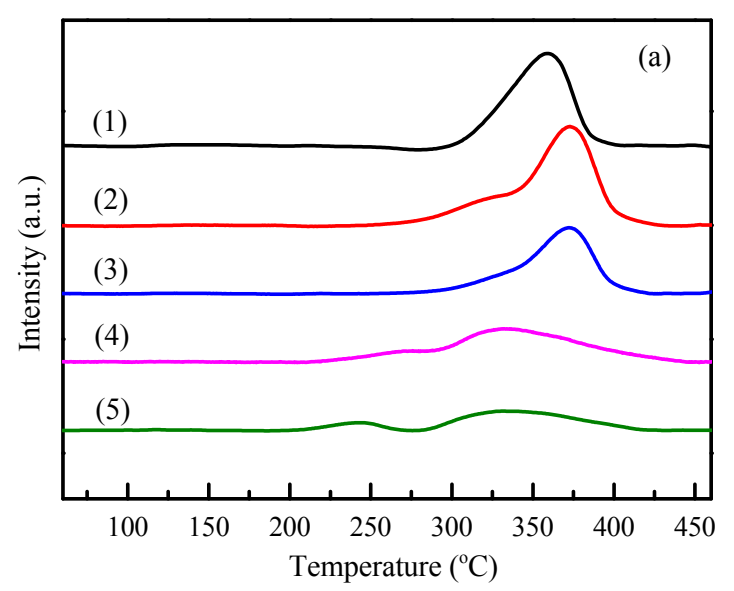

Fig. 3. $\mathrm{CO}_{2}$-TPD (a) and $\mathrm{NH}_{3}$-TPD (b) profiles of $\mathrm{Pd} / \mathrm{Mg}_{5} \mathrm{Al}-\mathrm{MMO}$ $\mathrm{Pd} / \mathrm{Mg}_{1} \mathrm{Al}-\mathrm{MMO}$ (5) multifunctional catalysts.

performed. In Fig. 3(a), the profile of $\mathrm{CO}_{2}$-TPD exhibits two desorption features: a slight one between 200 to $300{ }^{\circ} \mathrm{C}$ and a sharp one at $370{ }^{\circ} \mathrm{C}$. Generally, the temperature of $\mathrm{CO}_{2}$ desorption in the range of $200-420^{\circ} \mathrm{C}$ reflects the absence of the medium-strong-basic sites $[43,44]$. In this case, it could be assigned to the adsorption of $\mathrm{CO}_{2}$ on $\mathrm{Mg}^{2+-} \mathrm{O}^{2-}$ acid-base pairs on the layer of MMO support [40], and with decreasing Mg content among five catalysts, the area of $\mathrm{CO}_{2}$ desorption peak gradually decreased, suggesting that the number of basic sites declined on the surface of the given catalyst, which is consistent with the results reported in the literature [45-47]. The acidity of the catalysts was determined by $\mathrm{NH}_{3}$-TPD. As shown in Fig. $3 b$, there are several overlapping peaks in the range of $225-450{ }^{\circ} \mathrm{C}$ on the Pd/MgAl-MMO and Pd/Mg2Al-MMO samples, compared to the single sharp desorption peak at $350^{\circ} \mathrm{C}$ in the three other catalysts. The Lewis acid on all the catalysts resulted from accessible $\mathrm{Al}^{3+}$ cations in $\mathrm{Al}^{3+-} \mathrm{O}^{2--} \mathrm{Mg}^{2+}$ species, which could be ascribed to the medium-strong-acid sites [48]. In contrast to the trend of basicity, the total number of acidic sites of the catalysts decreased with increasing Mg content. Furthermore, the

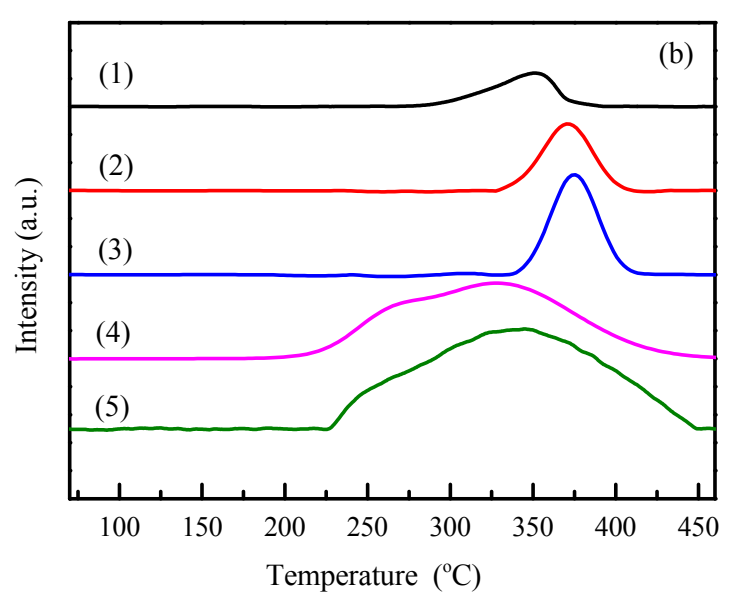

(1), Pd/Mg $\mathrm{Mg}_{4} \mathrm{Al}-\mathrm{MMO}$ (2), Pd/Mg $\mathrm{Al}-\mathrm{MMO}$ (3), Pd/Mg $2 \mathrm{Al}-\mathrm{MMO}$ (4), and corresponding number of acidic and basic sites were evaluated based on the peak area $[49,50]$, and the results show that the control of $\mathrm{Mg} / \mathrm{Al}$ ratio in the $\mathrm{LDH}$ precursor layer can result in a continuous change of the total number of acidic and basic sites in the obtained multifunctional catalysts.

The gradually tunable basicity and acidity on the surface of $\mathrm{Pd} / \mathrm{Mg}_{x} \mathrm{Al}$-MMO catalysts facilitate the further study of the synergistic effect of multi-site catalysts in the one-pot synthesis of the MIBK reaction. The catalytic performance of these five catalysts is shown in Fig. 4. For all the Pd/Mg $\mathrm{Al}-\mathrm{MMO}(x=1-5)$ catalysts, MIBK was the main product; however, the $\mathrm{Mg} / \mathrm{Al}$ ratio had a considerable effect on acetone conversion and yield to MIBK. Specifically, with increasing Mg content in the catalysts, the selectivity of MIBK showed a rising trend overall, while the selectivity to byproduct IPA showed the opposite trend. It was found that the conversion of acetone for different $\mathrm{Mg} / \mathrm{Al}$ ratios can be described as a volcano curve, and the $\mathrm{Pd} / \mathrm{Mg}_{3} \mathrm{Al}-\mathrm{MMO}$ catalyst possessing a medium number of acidic and basic sites exhibited the best catalytic performance with 82.8\% MIBK selectivity at $38.5 \%$ acetone conversion. 


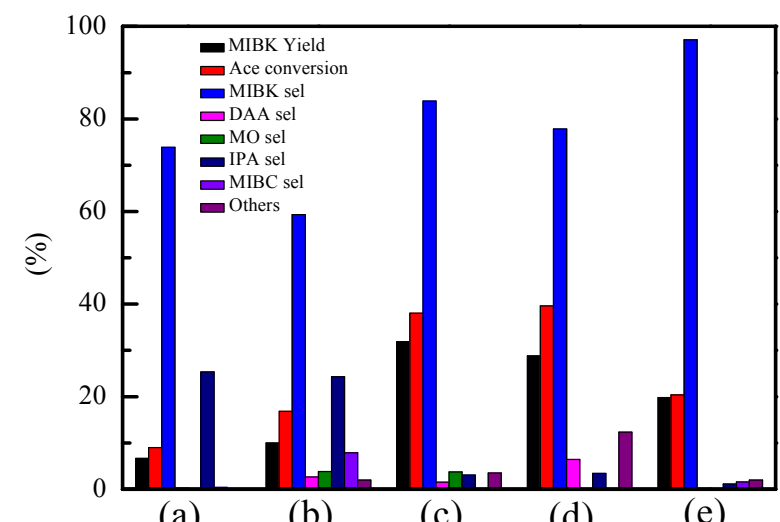

Fig. 4. Catalytic properties of Pd/Mg $1 \mathrm{Al}-\mathrm{MMO}(\mathrm{a}), \mathrm{Pd} / \mathrm{Mg}_{2} \mathrm{Al}-\mathrm{MMO}(\mathrm{b})$, $\mathrm{Pd} / \mathrm{Mg}_{3} \mathrm{Al}-\mathrm{MMO}$ (c), Pd/Mg $4 \mathrm{Al}-\mathrm{MMO}$ (d), and Pd/Mg $\mathrm{Ml}-\mathrm{MMO}$ (e) catalysts.

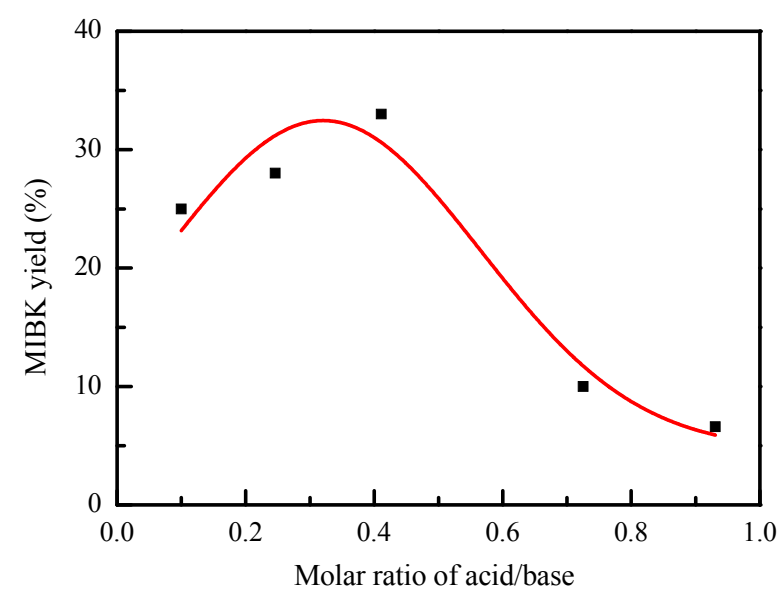

Fig. 5. The relation between molar ratio of acid/base and yield of MIBK.

In the series of $\mathrm{Pd} / \mathrm{Mg}_{x} \mathrm{Al}-\mathrm{MMO}$ multifunctional catalysts, the different $\mathrm{Mg} / \mathrm{Al}$ ratios represent the change in the number of acidic/basic sites. The number of acidic sites on the catalyst decreased rapidly as the Mg content increased, while the basicity of the catalyst showed the opposite trend. Thus, we established the connection between the yield of MIBK and the molar ratio of acidic/basic sites. As shown in Fig. 5, enhanced yield of MIBK was observed with increasing $\mathrm{Mg} / \mathrm{Al}$ molar ratio and reached a maximum value at the $\mathrm{Mg} / \mathrm{Al}$ molar ratio of 3 ; the ratio of acidic/basic sites at this point was about 0.4 . Thereafter, the yield of MIBK decreased sharply with the further increase of acidity over the multifunctional catalysts, which was caused by limited acetone conversion. The change of the relationship curve suggests that the number of acid/base sites has a direct and significant effect on yield of MIBK in this one-pot synthesis reaction.

\subsection{Effect of metal loading on the performance of the $\mathrm{Pd} / \mathrm{Mg}_{3} \mathrm{Al}-\mathrm{MMO}$ catalyst}

In addition to the synergistic effect of the acidic and basic sites, a series of $\mathrm{Pd} / \mathrm{Mg}_{3} \mathrm{Al}-\mathrm{MMO}$ catalysts with different metal loading were synthesized and tested in a one-step synthesis of

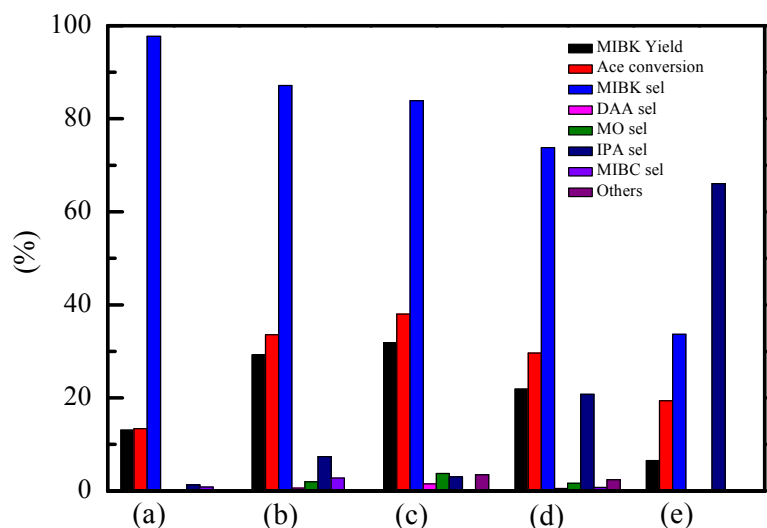

Fig. 6. Catalytic properties of $\mathrm{Pd} / \mathrm{Mg}_{3} \mathrm{Al}-\mathrm{MMO}$ with a Pd loading of $0.01 \%$ (a), $0.05 \%$ (b), $0.1 \%$ (c), $0.2 \%$ (d), and $1.0 \%$ (e).

MIBK from acetone to study the influence of metallic site density on the catalytic performance of the $\mathrm{Pd} / \mathrm{Mg}_{3} \mathrm{Al}-\mathrm{MMO}$ multifunctional catalyst. As shown in Fig. 6, the conversion of acetone increased with $\mathrm{Pd}$ loading from $0.01 \%$ to $0.1 \%$, and reached a maximum $(38 \%)$ at $0.1 \%$ Pd loading. Lower acetone conversion over $0.01 \mathrm{wt} \% \mathrm{Pd} / \mathrm{Mg} 3 \mathrm{Al}-\mathrm{MMO}$ catalyst may be due to the deactivation of the oxide catalyst, which is unavoidable for aldol condensation on metal oxides [51]. However, when the density of metallic sites rose to a certain value, it was found that MIBK selectivity decreased sharply and there was an obvious increase of IPA, which is the by-product from acetone hydrogenation. It is believed that the excessive number of metallic sites lead to the redundant dissociation of hydrogen, which then directly caused the hydrogenation of acetone to produce IPA, rather than the condensation reaction to generate DAA. Therefore, the optimal amount of Pd loading on $\mathrm{Pd} / \mathrm{Mg}_{3} \mathrm{Al}-\mathrm{MMO}$ multifunctional catalyst is $0.1 \%$, and it is the equilibrium point of the acidic/basic/metallic active sites that produces the maximum yield of the MIBK.

\subsection{Proximity effect in multifunctional catalyst}

In the tandem reaction, the performance of a multifunctional catalyst is not only affected by the nature of each site and the corresponding quantity-synergy; the proximity of the active sites has been reported to exert significant influence on catalytic property [52,53]. Therefore, the study of multi-site proximity is of great significance for understanding and then designing an efficient multifunctional catalyst for this tandem reaction. In our case, the research on the proximity effect between acidic/basic/metallic sites was carried out by a physical mixing experiment. Increasing the distance between the active sites (e.g. one site away from the other two or three sites away from each other), poorer catalytic performance was obtained compared to the catalyst with closest proximity of active sites, as listed in Table 4. For example, the physical mixing catalyst $\left(\mathrm{Pd} / \mathrm{C}+\mathrm{MgO}+\mathrm{Al}_{2} \mathrm{O}_{3}\right)$, which was prepared by the loading of $\mathrm{Pd}$ on active carbon and physical mixing with $\mathrm{MgO}$ and $\mathrm{Al}_{2} \mathrm{O}_{3}$, showed the poorest acetone conversion (5.3\%). Compared to $\mathrm{Pd} / \mathrm{C}$ (inactive shown in Table 1), the addition of $\mathrm{MgO}$ and 
Table 4

Catalytic performance of intimate mixture catalysts a.

\begin{tabular}{|c|c|c|c|c|c|c|c|}
\hline \multirow{2}{*}{ Entry } & \multirow{2}{*}{ Sample } & \multirow{2}{*}{ Acetone conversion (\%) } & \multicolumn{4}{|c|}{ Selectivity (\%) } & \multirow{2}{*}{ MIBK yield (\%) } \\
\hline & & & DAA & MO & MIBK & Others & \\
\hline 1 & $0.1 \% \mathrm{Pd} / \mathrm{C}+\mathrm{MgO}+\mathrm{Al}_{2} \mathrm{O}_{3}(\mathrm{Pd}+\mathrm{B}+\mathrm{A})$ & 5.3 & 0.4 & 0.9 & 97.3 & 1.4 & 5.2 \\
\hline 2 & $0.1 \% \mathrm{Pd} / \mathrm{C}+\mathrm{MMO}(\mathrm{Pd}+\mathrm{B} / \mathrm{A})$ & 5.5 & 0.0 & 2.4 & 95.6 & 2.0 & 5.3 \\
\hline 3 & $\mathrm{MgO}+0.3 \% \mathrm{Pd} / \mathrm{Al}_{2} \mathrm{O}_{3}(\mathrm{Pd} / \mathrm{A}+\mathrm{B})$ & 9.9 & 0.0 & 0.5 & 96.1 & 3.4 & 9.5 \\
\hline 4 & $0.15 \% \mathrm{Pd} / \mathrm{MgO}+\mathrm{Al}_{2} \mathrm{O}_{3}(\mathrm{Pd} / \mathrm{B}+\mathrm{A})$ & 17.4 & 0.1 & 0.3 & 97.1 & 2.6 & 16.9 \\
\hline 5 & $0.1 \% \mathrm{Pd} / \mathrm{MMO}(\mathrm{Pd} / \mathrm{A} / \mathrm{B})$ & 38.2 & 3.0 & 7.4 & 82.8 & 6.8 & 31.6 \\
\hline
\end{tabular}

Note that all five samples were prepared with the same Pd loading and $\mathrm{Mg} / \mathrm{Al}$ atomic ratio (A for acid sites and $\mathrm{B}$ for basic sites).

$\mathrm{Al}_{2} \mathrm{O}_{3}$ in the catalytic system facilitates the conversion of acetone (entry 1). Besides, the increased proximity of metal sites to acid sites or basic sites could double the conversion of acetone (entries 3 and 4), indicating that a small distance between active sites could truly enhance the catalytic performance of a given catalyst in this tandem reaction. Therefore, the catalyst obtained by the introduction of $\mathrm{MgO}$ and $\mathrm{Al}_{2} \mathrm{O}_{3}$ into the MgAl-MMO structure followed by the loading of Pd, which possessed the closest proximity among metallic sites, acidic sites, and basic sites, turned out to be the preferable one, exhibiting $38.2 \%$ acetone conversion (entry 5). The unique properties of MMO materials, particularly, the distance between acidic/basic sites at atomic level, make MMO an extremely promising material in the tandem reaction.

\subsection{A proposed mechanism for multifunctional catalysts}

Based on the above results, a possible mechanism is proposed, which is shown in Scheme 1. In a Pd/MMO catalyst, $\alpha-\mathrm{H}$ of acetone initially adsorbs on the $\mathrm{O}^{\delta \text { - }}$ basic site in $\mathrm{Al}^{3+-} \mathrm{O}^{2-}-\mathrm{Mg}^{2+}$, which can break the $\mathrm{C}-\mathrm{H}$ bond and then form a carbanion intermediate [51]. Subsequently, the formed carbanion reacts with another acetone, leading to formation of DAA. The acidic site $\mathrm{Al}^{\delta+}$ from $\mathrm{Al}^{3+-} \mathrm{O}^{2-}-\mathrm{Mg}^{2+}$ captures the $\mathrm{O}-\mathrm{H}$ functional group in DAA, resulting in a dehydration reaction to create the $\mathrm{C}=\mathrm{C}$ bond, followed by hydrogenation with the dissociated hydrogen that was produced at the Pd site to form MIBK. It can be seen from the reaction process that intimate and continuous active sites could facilitate the continuity of the tandem reaction. Acetone molecules are activated gradually by basic/acidic/metallic sites on the Pd/MMO multifunctional catalyst, greatly reducing the diffusion time of intermediate species from one active site to another, maximize the efficiency of the continuous reaction, resulting in high MIBK yield [54].

\subsection{Optimization of the multifunctional catalyst}

The synthesis method was found to greatly influence the properties and performance of a catalyst [55,56]. Herein, $\mathrm{Mg}_{3} \mathrm{Al}-\mathrm{MMO}$-supported Pd catalysts were also prepared via DP methods and the test results are listed in Table 5. Under the same conditions, $88.36 \%$ selectivity to MIBK was achieved at $42.11 \%$ acetone conversion on the $\mathrm{Pd} / \mathrm{Mg}_{3} \mathrm{Al}-\mathrm{MMO}_{\mathrm{DP}}$ catalyst. The yield of MIBK on the Pd/ $\mathrm{Mg}_{3} \mathrm{Al}-\mathrm{MMO}$ DP catalyst was $37.3 \%$, which is $17.6 \%$ higher than that of the $\mathrm{Pd} / \mathrm{Mg}_{3} \mathrm{Al}-\mathrm{MMO}$ catalyst prepared by an impregnation method. Especially, the $\mathrm{Pd} / \mathrm{Mg}_{3} \mathrm{Al}-\mathrm{MMO}_{\mathrm{DP}}$ multifunctional catalyst exhibits excellent performance compared to the catalysts reported to date (Table

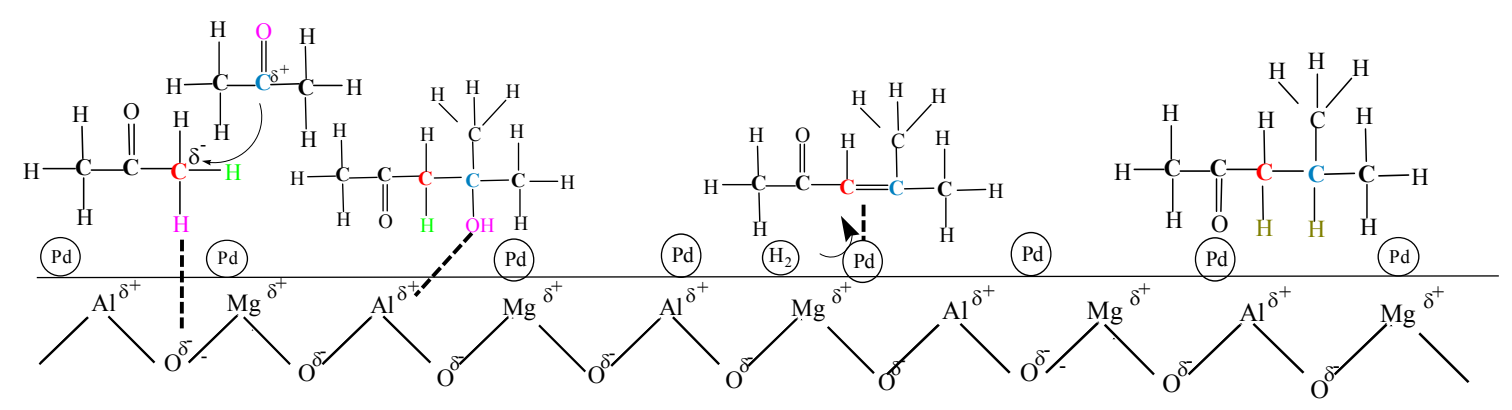

Scheme 1. Proposed mechanism of one-pot synthesis of MIBK from acetone on a Pd/MMO multifunctional catalyst.

Table 5

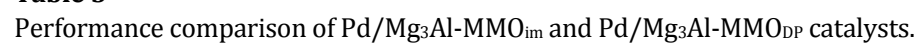

\begin{tabular}{|c|c|c|c|c|c|}
\hline \multirow{2}{*}{ Catalyst } & \multirow{2}{*}{ Conversion (\%) } & \multicolumn{3}{|c|}{ Selectivity (\%) } & \multirow{2}{*}{ MIBK yield (\%) } \\
\hline & & MIBK & DAA & MO & \\
\hline $\mathrm{Pd} / \mathrm{Mg}_{3} \mathrm{Al}-\mathrm{MMO}_{\text {im }}$ & 38.2 & 82.8 & 3.0 & 7.4 & 31.6 \\
\hline $\mathrm{Pd} / \mathrm{Mg}_{3} \mathrm{Al}-\mathrm{MMO}_{\mathrm{DP}}$ & 42.1 & 88.4 & 2.1 & 0.3 & 37.2 \\
\hline $0.1 \% \mathrm{Pd} / \gamma-\mathrm{Al}_{2} \mathrm{O}_{3}[20]$ & 26.3 & 82.5 & 10.8 & N.D. & 21.7 \\
\hline 1\%Pd/Zn-Cr oxide [57] & 28.5 & 80.4 & 4.6 & 0.4 & 22.9 \\
\hline $\mathrm{Pd} / 40 \mathrm{SO}_{3} \mathrm{H}-\mathrm{E}-\mathrm{HS}[17]$ & 20.6 & 90.3 & 5.3 & 0.0 & 18.6 \\
\hline T500/Cor\&Pd/Cor [58] & 39.7 & 82.0 & 12.4 & 0.0 & 32.6 \\
\hline 0.87\%/Pd@MIL-101 [59] & 70.6 & 46.8 & 15.4 & 8.7 & 33.0 \\
\hline
\end{tabular}


5). The $\mathrm{CO}_{2}$ and $\mathrm{NH}_{3}$-TPD analyses (Fig. S2) suggest that the surface of the catalyst treated by $\mathrm{NaOH}$ solution in the DP method contained more acidic and basic sites compared to the catalyst treated by the impregnation method. The number of acidic and basic sites on the $\mathrm{Pd} / \mathrm{Mg}_{3} \mathrm{Al}-\mathrm{MMO}_{\mathrm{DP}}$ catalyst surface was $86 \mu \mathrm{mol}_{\mathrm{NH} 3} / \mathrm{g}$ and $214 \mu \mathrm{molco}_{\mathrm{co}} / \mathrm{g}$ respectively, and the molar ratio of acid/base (ca. 0.4 ) is located at the peak of the obtained volcano curve (Fig. 5). Moreover, the obtained $\mathrm{Pd} / \mathrm{Mg}_{3} \mathrm{Al}-\mathrm{MMO}_{\mathrm{DP}}$ catalyst also exhibited an enhanced hydrogenation ability of MO, as shown in Table 5, which is also favorable for improved MIBK yield. Furthermore, the $\mathrm{Pd} / \mathrm{Mg}_{3} \mathrm{Al}-\mathrm{MMO}$ DP catalyst possessed fairly good stability over 4 cycling reactions (Fig. 7). Therefore, the Pd/ $\mathrm{Mg}_{3} \mathrm{Al}-\mathrm{MMO}$ DP multifunctional catalysts can be considered as efficient and environmentally friendly heterogeneous catalysts, showing a promising prospect in the industrial application of the one-pot synthesis of MIBK from acetone.

\section{Conclusions}

In this paper, we systematically studied the synergistic effect of the nature, density, and proximity of basic/acidic/metallic sites on multifunctional catalysts for the one-pot synthesis of MIBK from acetone. The catalytic performance of various $\mathrm{Pd} / \mathrm{acid}$ and $\mathrm{Pd} /$ base bifunctional catalysts suggests that the strength of acidity and basicity on the catalysts plays a significant role in the specific steps in the tandem reaction. In addition, we found that the catalytic properties of the multifunctional catalysts were more than just a superposition of acidic and basic sites. Further research on the influence of the density of acidic/basic sites was then carried out by adjusting the ratio of $\mathrm{Mg} / \mathrm{Al}$ to achieve the continuous change in the number of acidic and basic sites, and it was revealed that the maximum yield of MIBK was obtained by the multifunctional $\mathrm{Pd} / \mathrm{Mg}_{3} \mathrm{Al}-\mathrm{MMO}$ with $0.1 \%$ Pd loading and 0.4 acidic/basic molar ratio. Moreover, the proximity test indicated that the intimate and continuous active sites could shorten the diffusion time of intermediate species from each active site, leading to the maximum efficiency of the tandem reaction. Notably, the optimal Pd/Mg $\mathrm{Mgl}_{3} \mathrm{Al}$ MMODP catalyst with $37.2 \% \mathrm{MIBK}$ yield exhibited good stability over four recycling tests.

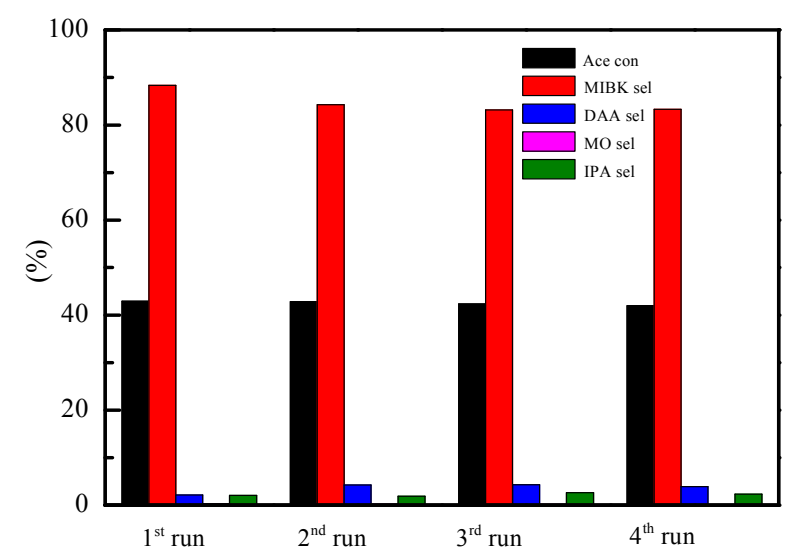

Fig. 7. Reusability of the $\mathrm{Pd} / \mathrm{Mg}_{3} \mathrm{Al}-\mathrm{MMO} \mathrm{DP}_{\mathrm{DP}}$ catalyst.

\section{References}

[1] A. Corma, S. Iborra, A. Velty, Chem. Rev., 2007, 107, 2411-2502.

[2] E. L. Kunkes, D. A. Simonetti, R. M. West, J. C. Serrano-Ruiz, C. A. Gärtner, J. A. Dumesic, Science, 2008, 322, 417-421.

[3] M. Martínez-Ortiz, D. Tichit, P. Gonzalez, B. Coq, J. Mol. Catal. A, 2003, 201, 199-210.

[4] H. R. Yue, Y. J. Zhao, X. B. Ma, J. L. Gong, Chem. Soc. Rev., 2012, 41, 4218-4244.

[5] N. Yan, C. Zhao, C. Luo, P. J. Dyson, H. C. Liu, Y. Kou, J. Am. Chem. Soc., 2006, 128, 8714-8715.

[6] M. J. Climent, A. Corma, A. Iborra, M. J. Sabater, ACS Catal., 2014, 4, 870-891.

[7] W. Wang, S. P. Wang, X. B. Ma, J. L. Gong, Chem. Soc. Rev., 2011, 40, 3703-3727.

[8] A. Corma, M. Boronat, M. J. Climent, S. Iborra, R. Montón, M. J. Sabater, Phys. Chem. Chem. Phys., 2011, 13, 17255-17261.

[9] K. Weissermel, H. J. Arpe, Industrial Organic Chemistry, fourth ed. Wiley-VCH, Weinheim, 2003.

[10] D. S. Abrams, J. M. Prausnitz, AIChE J., 1975, 21, 116-128.

[11] S. Wang, K. H. Yin, Y. C. Zhang, H. C. Liu, ACS Catal., 2013, 3, 2112-2121.

[12] M. Q. Zhao, R. M. Crooks, Angew. Chem. Int. Ed., 1999, 38, 364-366.

[13] M. D’Arino, F. Pinna, G. Strukul, Appl. Catal. B, 2004, 53, 161-168.

[14] S. Mandal, D. Roy, R. V. Chaudhari, M. Sastry, Chem. Mater., 2004, $16,3714-3724$.

[15] M. Adlim, M. A Bakar, K. Y. Liew, J. Ismail, J. Mol. Catal. A, 2004, 212, 141-149.

[16] K. H. Lin, A. N. Ko, Appl. Catal. A, 1996, 147, 259-265.

[17] P. Wang, S. Y. Bai, J. Zhao, P. P. Su, Q. H. Yang, C. Li, ChemSusChem, 2012, 5, 2390-2396.

[18] R. D. Hetterley, E. F. Kozhevnikova, I. V. Kozhevnikov, Chem. Commun., 2006, 782-784.

[19] S. M. Yang, Y. M. Wu, Appl. Catal. A, 2000, 192, 211-220.

[20] Y. Higashio, T. Nakayama, Catal. Today, 1996, 28, 127-131.

[21] Y. Z. Chen, B. J. Liaw, H. R. Tan, K. L. Shen, Appl. Catal. A, 2001, 205, 61-69.

[22] J. T. Feng, Y. F. He, Y. N. Liu, Y. Y. Du, D. Q. Li, Chem. Soc. Rev., 2015, 44, 5291-5319.

[23] Q. Wang, D. O'Hare, Chem. Rev., 2012, 112, 4124-4155.

[24] Q. Wang, H. H. Tay, D. J. W. Ng, L. W. Chen, Y. Liu, J. Chang, Z. Y. Zhong, J. Z. Luo, A. Borgna, ChemSusChem, 2010, 3, 965-973.

[25] Q. Wang, D. O'Hare, Chem. Commun., 2013, 49, 6301-6303.

[26] S. P. Wang, S. L. Yan, X. B. Ma, J. L. Gong, Energy Environ. Sci, 2011, 4, 3805-3819.

[27] Y. N. Liu, J. Y. Zhao, Y. F. He, J. T. Feng, T. Wu, D. Q. Li, J. Catal., 2017, $348,135-145$.

[28] E. Pérez-Barrado, M. C. Pujol, M. Aguiló, J. Llorca, Y. Cesteros, F. Díaz, J. Pallarès, L. F. Marsal, P. Salagre, Chem. Eng. J., 2015, 264, 547-556.

[29] N. Das, D. Tidier, R. Durand, P. Graffin, B. Coq, Catal. Lett., 2001, 71, 181-185.

[30] M. J. Martínez-Ortiz, D. Tichit, P. Gonzalez, B. Coq, J. Mol. Catal. A, 2003, 201, 199-210.

[31] A. A. Nikolopoulos, B. W. L. Jang, J. J. Spivey, Appl. Catal. A, 2005, 296, 128-136.

[32] F. Winter, A. J. Dillen, K. P. de Jong, J. Mol. Catal. A, 2004, 219, 273-281.

[33] E. M. Köck, M. Kogler, T. Bielz, B. Klözer, S. Penner, J. Phys. Chem. C, 


\section{Graphical Abstract}

Chin. J. Catal., 2018, 39: 1384-1394 doi: 10.1016/S1872-2067(18)63092-X

Fabrication of Pd-based metal-acid-alkali multifunctional catalysts for one-pot synthesis of MIBK

Rui Ma, Yunpeng Li, Guandong Wu, Yufei He*, Junting Feng,

Yingying Zhao *, Dianqing Li

Beijing University of Chemical Technology

For multifunctional catalysts, the catalytic properties are more than just a collection of active sites, and the $\mathrm{Pd} / \mathrm{Mg}_{3} \mathrm{Al}-\mathrm{MMO}$ multifunctional catalyst containing intimate acidic/basic/metallic sites exhibits excellent performance in the one-pot synthesis of MIBK from acetone.

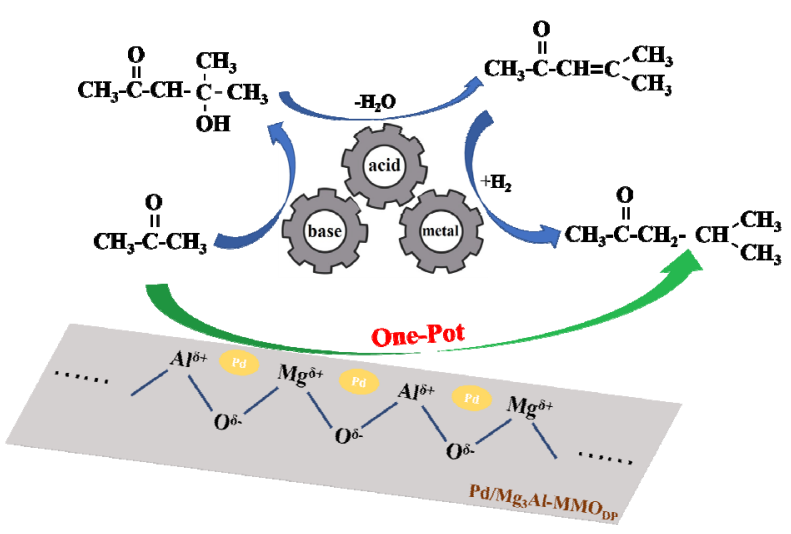

2013, 117, 17666-17673.

[34] K. Bhattacharyya, A. Danon, B. K. Vijayan, K. A. Gray, P. C. Stair, E. Weitz, J. Phys. Chem. C, 2013, 117, 12661-12678.

[35] E. A. Bielinski, P. O. Lagaditis, Y. Y. Zhang, B. Q. Mercado, C. Würtele, W. H. Bernskoetter, N. Hazari, S. Schneider, J. Am. Chem. Soc., 2014, 136, 10234-10237.

[36] P. C. Liu, J. T. Feng, X. M. Zhang, Y. J. Lin, D. G. Evans, D. Q. Li, J. Phys. Chem. Solids, 2008, 69, 799-804.

[37] K, Nakajima, R, Noma, M, Kitano, M, Hara, J. Mol. Catal. A, 2014, 388, 100-105.

[38] C. A. Monteiro, D. Costa, J. L. Zotin, D. Cardoso, Fuel, 2015, 160, 71-79.

[39] K. Saravanan, B. Tyagi, R. S. Shukla, H. C. Bajaj, Appl. Catal. B, 2015, $172,108-115$.

[40] M. Shirotori, S. Nishimura, K. Ebitani, Catal. Sci. Technol, 2016, 6, 8200-8211.

[41] M. J. Climent, A. Corma, P. De Frutos, S. Iborra, M. Noy, A. Velty, P. Concepción, J. Catal., 2010, 269, 140-149.

[42] F. Prinetto, G. Ghiotti, R. Dura, D. Tichit, J. Phys. Chem. B, 2000, 104, 11117-11126.

[43] J. I. Di Cosimo, V. K. Díez, M. Xu, E. Iglesia, C. R. Apesteguía, J. Catal., 1998, 178, 499-510.

[44] Q. S. Pan, J. X. Peng, T. J. Sun, S. Wang, S. D. Wang, Catal. Commun., 2014, 45, 74-78.

[45] P. Liu, C. Li, E. J. M. Hensen, Chem. Eur. J., 2012, 18, 12122-12129.
[46] P. Liu, M. Derchi, E. J. Hensen, Appl. Catal. A, 2013, 467, 124-131.

[47] P. Liu, M. Derchi, E. J. Hensen, Appl. Catal. B, 2014, 144, 135-143.

[48] Q. Wang, Z. Y. Zhou, Y. J. Lai, Y. You, J. G. Liu, X. L. Wu, E. Terefe, C. Chen, L. Song, M. Rauf, N. Tian, S. G. Sun, J. Am. Chem. Soc., 2014, 136, 10882-10885.

[49] W. Qi, W. Liu, B. S. Zhang, X. M. Gu, X. L. Guo, D. S. Su, Angew. Chem. Int. Ed., 2013, 52, 14224-14228.

[50] R. C. Klet, Y. Y. Liu, T. C. Wang, J. T. Hupp, O. K. Farha, J. Mater. Chem. A, 2016, 4, 1479-1485.

[51] S. Wang, K. Goulas, E. Iglesia, J. Catal., 2016, 340, 302-320.

[52] G. N. Li, E. A. Pidko, E. J. M. Hensen, Catal. Sci. Technol, 2014, 4, 2241-2250.

[53] J. Wei, Q. J. Ge, R. W. Yao, Z. Y. Wen, C. Y. Fang, L. S. Guo, H. Y. Xu, J. Sun, Nat. Commun., 2017, 15174, 1-8.

[54] J. Zečević, G. Vanbutsele, K. P. De Jong, J. A. Martens, Nature, 2015, $528,245-248$.

[55] Y. Xu, M. Wu, Y. Liu, X. Z. Feng, X. B. Yin, X. W. He, Y. K. Zhang, Chem. Eur. J., 2013, 19, 2276-2283.

[56] N. E. Kolli, L. Delannoy, C. Louis, J. Catal, 2013, 297, 79-92.

[57] F. Al-Wadaani, E. F. Kozhevnikova, I. V. Kozhevnikov, J. Catal., 2008, 257, 199-205.

[58] S. D. Zhang, P. C. Wu, L. Q. Yang, Y. H. Zhou, H. Zhong, Catal. Commun., 2015, 71, 61-64.

[59] Y. Y. Pan, B. Z. Yuan, Y. W. Li, D. H. He, Chem. Commun., 2010, 46, $2280-2282$.

\section{Pd-基金属-酸-碱多功能催化剂的制备及其丙酮一步法合成MIBK性能研究

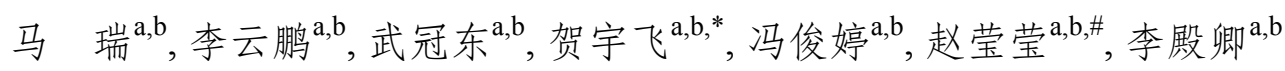 \\ a 北京化工大学, 化工资源有效利用国家重点实验室, 北京100029 \\ b 北京化工大学, 北京市多级结构催化材料工程技术研究中心, 北京 100029}

摘要: 甲基异丁基酮 (MIBK) 是一种重要的化学品, 广泛应用于涂料以及有机合成领域, 下游产品包括特种涂料溶剂、高 品质脱蜡溶剂和高性能橡胶防老剂等. 近年来随国民经济的快速发展, 甲基异丁基酮的年需求量与价格逐年上升, 应用领 域也不断拓宽. 因此, 开展 MIBK 绿色合成工艺的研究对提高原子经济性、打破国际技术壁垒以及满足国内市场需求具有 重要意义. 目前生产 MIBK 最绿色、高效的生产方法是丙酮一步法, 包括缩合、脱水以及加氢等一系列反应过程, 该工艺 顺利实施的关键在于所使用的催化剂. 根据丙酮一步法合成 MIBK 反应特点, 所用催化剂表面必须具备多种催化活性中 
心, 从而保证缩合、脱水以及加氢反应的顺利进行, 实现从反应物到产物的高效转化. 因此, 高活性和高选择性多功能催化 剂的制备是提高 MIBK 生产效率的有效途径.

本文采用浸渍法将具有加氢活性的贵金属 Pd 负载在表面具有丰富酸性位点或碱性位点的固体酸或固体碱氧化物载 体上, 制备了 $\mathrm{Pd} / \mathrm{MO}_{x}(\mathrm{M}=\mathrm{Ti}, \mathrm{Ce}, \mathrm{Al}, \mathrm{Si}, \mathrm{La}, \mathrm{Ca}$ 和 $\mathrm{Mg})$ 双功能催化剂, 并用于丙酮一步法合成 $\mathrm{MIBK}$ 反应中. 结果表明, $\mathrm{Pd}$ 基金属-酸/碱双功能催化剂均可以催化该连串反应的进行, 其性能高于 $\mathrm{Pd}$ 基金属-酸双功能催化剂, 其中 $\mathrm{Pd} / \mathrm{MgO}$ 催化剂 上丙酮转化率为 $30.67 \%$, MIBK 产率可达 $27.61 \%$. 构效关系研究显示, 催化剂表面酸性位点和碱性位点对于该连串反应的 各反应步骤催化性能有所不同, 其中碱性位点有利于丙酮缩合反应, 而酸性位点有利于二丙酮醇脱水反应, 且强路易斯碱 性中心位点可以更好的催化缩合反应的进行, 同时中强度路易斯酸性中心位点具有最佳的催化脱水反应的能力. 此外, 表 面具有最强路易斯碱性中心位点 $\mathrm{Pd} / \mathrm{La}_{2} \mathrm{O}_{3}$ 催化剂并未表现出最高的MIBK产率, 说明在丙酮一步法合成MIBK反应中, $\mathrm{Pd}$ 基双功能催化剂表面各位点间的协同对其催化性能具有重要的影响.

本文进一步采用水热法和沉淀沉积法制备了系列 $\mathrm{MgTiO}_{x} 、 \mathrm{MgAlO}_{x}$ 和 $\mathrm{CaTiO}_{x}$ 二元复合氧化物 $(\mathrm{MMO})$ 以及 $\mathrm{CaMgAlO}_{x}$ 和 $\mathrm{TiMgAlO}_{x}$ 三元MMO, 并以其为载体, 通过浸渍焙烧还原制备 Pd 基多功能催化剂, 并用于丙酮一步法合成MIBK反应中, 发现Pd/MgAl-MMO多功能催化剂具有最高的催化活性及 MIBK 产率. 对其表面多功能位点数量进行调变, 并通过 XRD、 $\mathrm{CO}_{2}-\mathrm{TPD} 、 \mathrm{NH}_{3}-\mathrm{TPD}$ 、吡啶红外、 $\mathrm{CO}_{2}$ 红外和HRTEM等进行表征, 结果表明, 经过 $450{ }^{\circ} \mathrm{C}$ 焙烧酸碱中心摩尔量比为 0.4 的 $0.1 \% \mathrm{Pd} / \mathrm{Mg}_{3} \mathrm{Al}-\mathrm{MMO}$ 多功能协同催化剂三种催化活性中心位点协同作用最佳, 其丙酮转化率为 $38.20 \%$, MIBK产率可达 $31.63 \% . \mathrm{Pd} / \mathrm{Mg}_{3} \mathrm{AlMMO}$ 多功能协同催化剂三种活性位点接近性研究表明, 在多功能催化剂中分离酸中心活性位点、碱中 心活性位点以及加氢活性位点后, 获得的双功能催化剂产率均明显下降, 说明 $\mathrm{Pd} / \mathrm{Mg}_{3} \mathrm{Al}-\mathrm{MMO}$ 多功能催化剂在三种活性位 点相互接近时才能更好催化反应的进行. 根据多功能催化剂构效关系研究结果, 对各催化活性中心的密度及分布进行调 控, 结果显示, 通过沉淀沉积法制备的Pd/Mg $\mathrm{Mg}_{3} \mathrm{Al}-\mathrm{MMO}$ 催化剂性能进一步提高, 丙酮转化率为 $42.11 \%$, 产率高达 $37.20 \%$.

关键词: 一步法合成甲基异丁基酮; 多功能催化剂; 钯; $\mathrm{Mg}_{3} \mathrm{Al}$ 复合金属氧化物; 协同效应; 位点接近性

收稿日期: 2018-02-26. 接受日期: 2018-04-24. 出版日期: 2018-08-05.

*通讯联系人. 传真: (010)64425385; 电子邮箱: yfhe@mail.buct.edu.cn

\#通讯联系人. 传真: (010)64437866; 电子邮箱: zhaoyy@mail.buct.edu.cn

基金来源：国家重点研发计划（2016YFB0301601); 国家自然科学基金 (21706009); 中央高校基本科研业务费专项资金 (BUCTRC201725, JD1816).

本文的电子版全文由Elsevier出版社在ScienceDirect上出版(http://www.sciencedirect.com/science/journal/18722067). 